\title{
Non-thyroidal illness syndrome predicts outcome in adult critically ill patients: a systematic review and meta-analysis
}

\author{
Josi Vidart ${ }^{1,2}$, Paula Jaskulski ${ }^{3}$, Ana Laura Kunzler ${ }^{3}$, Rafael Aguiar Marschner ${ }^{1}$, André Ferreira de Azeredo da Silva ${ }^{3}$ \\ and Simone Magagnin Wajner (1D) 1,3 \\ ${ }^{1}$ Thyroid Section, Endocrine Division, Hospital de Clínicas de Porto Alegre, Universidade Federal do Rio Grande do Sul, Porto Alegre, Rio Grande do Sul, Brazil \\ ${ }^{2}$ Intensive Care Unit, Hospital de Clínicas de Porto Alegre, Porto Alegre, Rio Grande do Sul, Brazil \\ ${ }^{3}$ Internal Medicine Division, Hospital de Clínicas de Porto Alegre, Internal Medicine Department, Universidade Federal do Rio Grande do Sul, Porto Alegre, \\ Rio Grande do Sul, Brazil
}

Correspondence should be addressed to S M Wajner: simone.wajner@ufrgs.br

\begin{abstract}
We performed a systematic review and meta-analysis to comprehensively determine the prevalence and the prognostic role of non-thyroidal illness syndrome (NTIS) in critically ill patients. We included studies that assessed thyroid function by measuring the serum thyroid hormone (TH) level and in-hospital mortality in adult septic patients. Reviews, case reports, editorials, letters, animal studies, duplicate studies, and studies with irrelevant populations and inappropriate controls were excluded. A total of 6869 patients from 25 studies were included. The median prevalence rate of NTIS was 58\% (IQR 33.2-63.7). In univariate analysis, triiodothyronine (T3) and free T3 (FT3) levels in non-survivors were relatively lower than that of survivors ( 8 studies for T3; standardized mean difference (SMD) 1.16; 95\% Cl, 0.41-1.92; $1^{2}=97 \% ; P<0.01$ ). Free thyroxine (FT4) levels in nonsurvivors were also lower than that of survivors (12 studies; SMD 0.54; $95 \% \mathrm{Cl}, 0.31-0.78$; $\left.I^{2}=83 \% ; P<0.01\right)$. There were no statistically significant differences in thyrotropin levels between non-survivors and survivors. NTIS was independently associated with increased risk of mortality in critically ill patients (odds ratio $(\mathrm{OR})=2.21,95 \% \mathrm{Cl}, 1.64-2.97, \mathrm{I}^{2}=65 \%$ $P<0.01)$. The results favor the concept that decreased thyroid function might be associated with a worse outcome in critically ill patients. Hence, the measurement of $\mathrm{TH}$ could provide prognostic information on mortality in adult patients admitted to ICU.
\end{abstract}

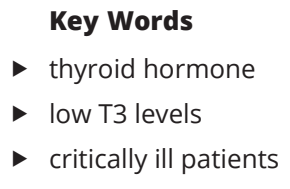

Endocrine Connections (2022) 11, e210504

\section{Introduction}

Thyroid hormones (TH) are essential for cellular growth, differentiation, and energetic regulation. Critical illness is frequently associated with alterations in TH metabolism not caused by abnormalities of the hypothalamicpituitary-thyroid function. These changes, collectively known as 'non-thyroidal illness syndrome' (NTIS) or 'low T3 syndrome' are characterized by low plasma concentrations of the biologic active hormone triiodothyronine (T3), low or normal plasma concentrations of thyroxine (T4), and elevated plasma levels of the inactive hormone reverse $\mathrm{T} 3$
(rT3) in the presence of normal thyrotropin (TSH) levels (1). The pathophysiology of NTIS is multifactorial. In the early phase, the peripheral TH metabolism is impaired, with reduced hormonal bioavailability consequent to the consumption of carrier proteins, as acute-phase proteins, and changes in the expression of transmembrane hormone transporters. Additionally, deranged iodothyronine deiodinases function causes a decrease of $\mathrm{T} 4$ to $\mathrm{T} 3$ conversion with a further raise in the inactivation of $\mathrm{T} 4$ to rT3. In the chronic course of the disease, inhibition of the

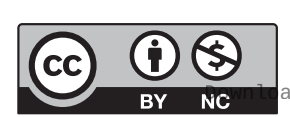

This work is licensed under a Creative Commons Attribution-NonCommercial 4.0 International License. ded from Bioscientifica.com at 04/26/2023 11:47:29AM 
hypothalamic-pituitary feedback loop also seems to occur, reflecting the severity of the disease $(2,3,4)$. Although NTIS has been studied for decades, it is still under debate whether these changes represent an adaptive mechanism in response to the demanding circumstances of disease or if it contributes to the persistence of organ dysfunctions and adversely impacts the outcome (5).

Currently, there are some well-established prognostic scores to estimate mortality and disease severity in the intensive care unit (ICU), such as APACHE IV, Simplified Acute Physiology Score (SAPS III), and Sequential Organ Failure Assessment (SOFA) $(6,7,8)$. APACHE IV score uses 12 physiological variables presented in the first $24 \mathrm{~h}$ of admission, evaluates chronic diseases, and the reason for admission at the ICU. SAPS III uses the worst values measured within the first $24 \mathrm{~h}$ of admission and reflects the severity of illness on admission. Alternatively, SOFA is based on simple measurements of organ function and was designed to track the evolution throughout the ICU stay. Although it was not designed for prognosis prediction, higher scores are associated with an increased risk of death (9). The risk-adjusted mortality provided by these prognostic scoring systems is mainly used to compare the quality of care provided by different ICUs, helping to identify institutional deficiencies in clinical outcomes and to emphasize areas for improvement. Prognostic scoring systems perform best at the cohort level due to the uncertainty concerning prediction in individual patients (10). Interestingly, some studies suggest a potential role of $\mathrm{TH}$ levels to predict mortality in hospitalized patients since T3 levels are lower in non-survivors than in survivors in different clinical settings $(11,12,13,14)$. Considering that most studies are underpowered and not primarily designed with this objective, whether NTIS may influence the outcome of critically ill patients admitted to ICU is still a matter of debate.

The aim of this study is to systematically review and provide evidence regarding a standardized definition, prevalence, and the association between NTIS and the outcome of critically ill patients admitted to ICU.

\section{Methods}

\section{Protocol and registration}

This systematic review adheres to the PRISMA (15) guidelines and was registered in the International Prospective Register of Systematic Reviews (PROSPERO CRD42020172989).

\section{Study objectives}

Our aim was to investigate the prognostic relevance of NTIS in critically ill adult patients. Particularly we focused on the following research questions:

(I) What is the prevalence of NTIS?

(II) Is NTIS associated with adverse clinical outcome?

\section{Eligibility criteria}

We included only cohort studies (either prospective or retrospective) and clinical trials which analyzed NTIS as a prognostic factor in adult patients in ICU settings.

The exclusion criteria were age younger than 18 years, animal studies, and articles that were not a cohort study or clinical trial. We considered articles written in English, Portuguese, and Spanish. No restriction to the date of publication was applied.

\section{Search strategy and study selection}

We conducted a systematic search on MEDLINE (via PubMed) and Embase databases from inception to March 2020. Comprehensive search queries included text words and descriptors (MeSH and Emtree) based on expressions 'Euthyroid Sick Syndrome', 'Non-thyroidal Illness Syndrome', and 'Low T3 Syndrome'. The complete search strategy for Embase and Pubmed is presented in Supplementary data 1 (see section on supplementary materials given at the end of this article).

Three independent reviewers (PRJ, ALK, and JV) assessed the records for inclusion based on the titles and abstracts. Abstracts that did not meet the inclusion criteria or that met the exclusion criteria were discarded. The remaining records and those abstracts that did not provide sufficient information to decide upon their exclusion were selected for full-text evaluation, which was performed by the same reviewers independently. A fourth reviewer (SW) solved the disagreements.

\section{Data collection and extraction}

Independent reviewers extracted the data using a standardized system. The following information was obtained: first author, year of publication, study design, sample size, and age distribution. Baseline values of thyroid function tests and definition of NTIS outcome used measures and main results, correlated to critical illness prognosis scores, conclusions, and limitations.

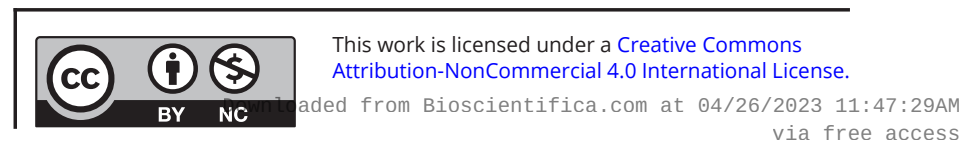


During the process of data extraction, the individual risk of bias of each study was assessed using the SIGN checklist (Supplementary data 2) (16). The research team checked and discussed the final extraction results.

\section{Statistical analysis}

The main analysis consisted of the investigation into an association between decreased peripheral $\mathrm{TH}$ levels and in-hospital mortality in adult patients. To determine the strength of the association between decreased THs and death, the standardized mean differences (SMD) were derived between survivor and non-survivor groups, using a random-effect model. The effect size estimation was performed by determining the SMD with their 95\% CI because the TH levels were reported with a wide variety of measurement units. SMD was calculated by the following equation: ((non-survivor group mean level - survivor group mean level)/pooled S.D.). The mean difference \pm S.D. was derived from the TH levels across the comparison groups. Since various units of TH were used in our study, we converted all into the recommended standard international units: T4 (nmol/L), T3 (nmol/L), free T4 (pmol/L), fT3 (pmol/L), and TSH $(\mu \mathrm{IU} / \mathrm{mL})$. The odds ratio (OR) with 95\% CI for all-cause mortality were pooled using a metaanalysis. For this purpose, only studies that presented results from multiregression analysis were included. In one study (17) that did not present the CI, we used a metaanalysis level imputation, based on methodologic quality and similarity of effect to estimate the missing values. This study used both the $\mathrm{I}^{2}$ statistic and Cochran's Q statistic to evaluate the heterogeneity. $\mathrm{I}^{2}$ higher than $40 \%$ indicated substantial heterogeneity across the included studies. Because of the difference in those included studies, we used the random-effects model to calculate the pooled prevalence of ORs. Subgroup analysis was performed by the type of admission and by quality assessment. Identification of publication bias was performed by the R packages 'meta' ( $\mathrm{R}$ version 3.3.2). The assessment of publication bias was by funnel plot and Egger's test. The asymmetry of the funnel plot and $P$-value $(<0.05)$ using Egger's test indicated that bias was present.

\section{Results}

\section{Trials identified through the search strategy}

Our search identified 3038 titles and abstracts of potentially eligible studies through database searching. After duplicate removal, 2078 records were screened and 38 full texts were assessed for eligibility. Of these, 13 did not provide information about the outcome of interest. Twenty-five studies with 6869 patients in total were included in the analysis (Fig. 1).

\section{Study characteristics and risk of bias}

Most of the records were from a small sample size, singlecenter studies including heterogeneous adult medical or mixed medical/surgical ICUs. Studies were conducted between 2001 and 2020. There was a high risk of bias (Table 1) resulting from the observational $(17,18,19,20,21,22$, $23,24,25,26,27,28,29,30,31,32,33,34,35,36,37,38$, $39,40,41)$ and retrospective study design $(17,18,22,30,31$, $37)$ used in the studies. The absence of statistical control for known confounders $(17,23,25,26,34,37)$ and for covariance with severity scores $(24,35)$ was also identified. Additionally, some trials did not deal with NTIS as the main research aspect and did not exclude patients with previous thyroid disease $(18,30)$.

\section{Diagnostic criteria and prevalence rates for NTIS}

Among the 25 studies, 16 reported the use of strict diagnostic criteria, while other studies used 'decreased

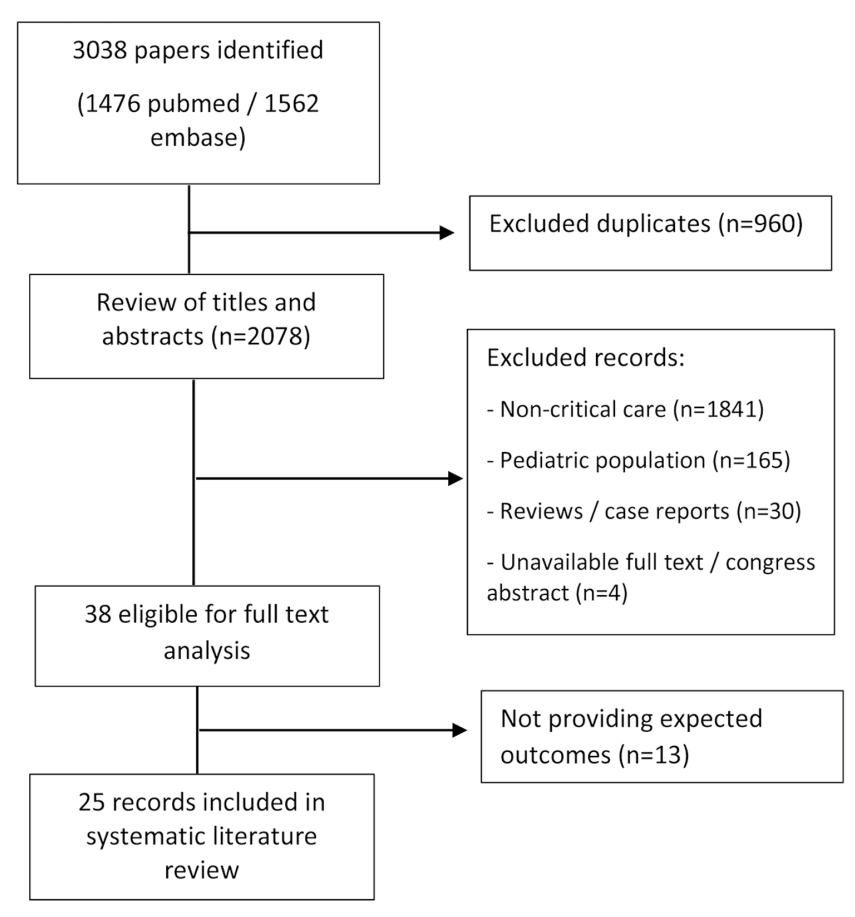

Figure 1

Flowchart of study selection. 


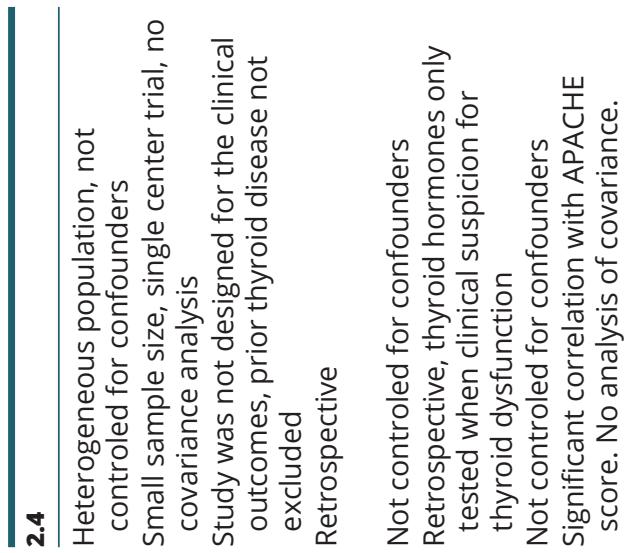

$|\mathrm{m}|$

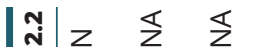

$|\overline{\mathrm{i}}|+$

$|\equiv|$

$|\stackrel{m}{*}|$

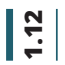

$|\equiv|$

$>>>z$

$>>$

$>>>$

$>>>$

$>>>>1$

$++++$

$>>z>$

$z>\quad z>$

$>z \quad z z>1$

$>>>>$

$|\stackrel{?}{\mid}|>>>>>>\quad>>>>>\mid$

$|q| z \quad>\quad z>>z \quad>>>>z \mid$

$|\stackrel{\infty}{*}|_{z} z \quad z \quad \mathbb{z} z z z \quad z>\quad z z z \mid$

$|\because| z>>\quad>>>>\quad>>>>>\mid$

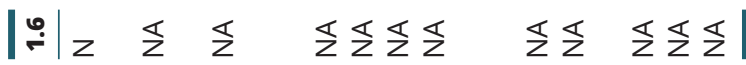

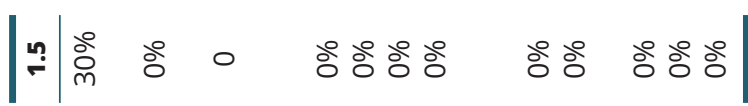

$|\nsubseteq|_{>}>>>>>\quad \& \frac{\pi}{z}>>z \mid$

$|\stackrel{m}{\mid r} \quad z \quad z \quad>>>>\quad>>z z z|$

$|\mathfrak{a}| z>>\quad>z>\quad z z \quad>>>$

$|\mp|>>>>>>>>>>\mid$

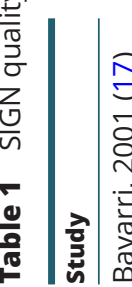

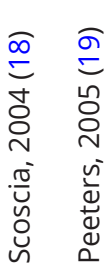

concentrations of T3 or FT3 or elevated concentrations of rT3' as the diagnostic criteria of NTIS, not considering the changes in TSH. As to the prevalence rate, only three studies did not describe the results of their samples. The median prevalence rate was 58\% (IQR 33.2-63.7). Four studies also described the prevalence of the combination of low T3 and T4 levels (median rate 26.1\% IRQ 13.6-32.3), pointing to a more severe form of the disease. Most studies $(16 / 25)$ collected blood samples for TH measurements on the first day of admission, as the timing of sampling may interfere with the results (Table 2).

\section{Prognostic role of NTIS}

In Table 3, we present the characteristics of the 25 included studies and the data on the association between serum $\mathrm{TH}$ levels and the outcome of critically ill patients. As to types of diseases, 14 studies presented information from patients admitted to ICU with non-specified clinical and surgical critical illness, 4 studies included patients admitted for cardiovascular causes - 2 from patients undergoing CABG $(19,39)$ and 2 from decompensated heart failure $(17,20), 3$ studies included patients with sepsis $(24,29,37), 1$ study was on patients with polytrauma (21) and 1 study was from a burning trauma center (22). Mortality rates varied greatly since they derived from a heterogeneous population with different follow-up periods.

Studies that reported differences between survivors and non-survivors according to four different serum $\mathrm{TH}$ levels (FT3, FT4, T3, and TSH) were included in the metaanalysis (Fig. 2). T3 and FT3 levels in non-survivors were lower than that of survivors (eight studies for T3: SMD 1.16; 95\% CI, 0.41-1.92; $\mathrm{I}^{2}=97 \% ; P<0.001 ; 11$ studies for FT3; SMD, 1.03; 95\% CI, 0.57-1.5; $\left.\mathrm{I}^{2}=95 \% ; P<0.01\right)$. FT4 levels in non-survivors were also lower than that of survivors (12 studies; SMD 0.54; 95\% CI, 0.31-0.78; $\mathrm{I}^{2}=83 \% ; P<0.01$ ). There were no statistically significant differences in TSH levels between non-survivors and survivors. Substantial heterogeneity was present in the results, so we performed an additional stratified analysis of studies according to methodologic quality assessment, finding that there was no significant decrease in heterogeneity in each subgroup.

Studies that reported OR for adverse outcome were pooled in a meta-analysis (Fig. 3). Data from 12 studies on outcome showed that NTIS was independently associated with increased risk of mortality in critically ill patients $\left(\mathrm{OR}=2.21,95 \% \mathrm{CI}, 1.64 .-2.97, \mathrm{I}^{2}=65 \% P<0.01\right)$. Subgroup analyses of patients admitted for cardiovascular causes or all other causes for admission suggested that NTIS was 
Table 2 Diagnostic criteria and prevalence rate for NTIS.

\begin{tabular}{l} 
Reference \\
\hline Bayarri, 2001 (17) \\
Scoscia, 2004 (18) \\
Peeters, 2005 (19) \\
Glikat, 2006 (20)
\end{tabular}

Sahana, $2008(22)$

Bello, 2009 (23)

Meyer, 2011 (24)

Tas, $2012(25)$

Todd, 2012 (26)

Nafae, 2013 (27)

Cerillo, 2014 (28)

Chuang, 2014 (29)

Naby, 2014 (30)

Galusova, 2015 (31)

Quari, 2015 (32)

Yasar, 2015 (33)

Hosny, 2015 (34)

Gutch, 2018 (35)

Padhi, 2018 (36)

Wang, 2019 (37)

Rothberger, 2019 (38)

Wang, 2019 (39)

Asai, 2020 (40)

\section{Definition of NTIS}

Type 1: FT3 < $2.3 \mu \mathrm{g} / \mathrm{mL}, \mathrm{rT3}>$

$0.50 \mathrm{ng} / \mathrm{mL}$ with normal T4;

Type 2: FT3 $<2.3 \mu \mathrm{g} / \mathrm{mL}$, FT4 $<0.9 \mathrm{ng} / \mathrm{dL}$, rT3 $>0.50$

$\mathrm{ng} / \mathrm{mL}$, and $\mathrm{TSH}<0.35 \mu \mathrm{IU} / \mathrm{L}$;

Type 3: FT4 $>1.8 \mathrm{ng} / \mathrm{dL}$ and $\mathrm{rT3}>0, .50 \mathrm{ng} / \mathrm{mL}$, T3 within normal limit

Reduced T3, T4 range from reduced to slightly elevated, 53\% with either normal or slightly suppressed TSH levels Low serum T3 and high rT3.

Low serum levels of T3, normal or low serum levels of $\mathrm{T} 4$, and normal or low serum levels of TSH. Low serum levels of fT3 with increase of $\mathrm{rT3}$ and normal-to-low serum concentrations of fT 4 and TSH. Decreased serum T3 and increased TSH, followed by a decrease in $\mathrm{T} 4$.

Low serum levels of T3, normal or low serum levels of T4, and normal or low serum levels of TSH.

Low T3 levels, increased rT3

levels, and/or low T4 levels with normal fT4 levels in the absence of an obvious thyroid disease

Low fT3 levels, although decreases in fT3, fT4, and TSH may occur in varying combinations Low T3

Low serum levels of $\mathrm{T} 3$ and high levels of $\mathrm{rT} 3$, with normal or low levels of T4 and normal or low levels of TSH.

Low circulating $\mathrm{T} 3$ levels in the absence of an intrinsic thyroid disease

Total T3 cutoff of $52.3 \mathrm{ng} / \mathrm{dL}$ (reference range 84 to $172 \mathrm{ng} / \mathrm{dL})$

Low serum levels of free and total T3 and high levels of rT3 accompanied by normal or low levels of T4 and TSH

Low T3 levels, increased reverse T3 levels, and/or low total T4 levels with normal fT4 levels in the absence of an obvious thyroid disease

Low FT4, FT3, and TSH levels.

FT3 levels below the lower limit, and/or fT4 within the normal or low limits and TSH levels within the normal or low limits

Low serum levels of T3 and high levels of rT3 accompanied by normal or low levels of T4 and TSH

Low levels T3 and high levels of rT3 with variable values of T4 and TSH in the low to normal range.

Group A: low T3 and normal or high T4.

Group B: low T3 and low T4.

High rT3 levels

FT3 $<2.3 \mathrm{pg} / \mathrm{mL}$

Decrease in levels of $\mathrm{T} 3$ and increase in levels of $\mathrm{rT3}$

Low FT3 $(<1.88 \mu \mathrm{L} / \mathrm{mL})$

\section{Prevalence}

Type 1: $55.4 \%$

Type 2: $10.9 \%$

Type 3: $1 \%$

Not described

$44 \%$ low T3

$22 \%$ low T3 and low T4

Not described

$80 \%$

$78 \%$ for low FT3

$30.3 \%$ for low FT3 and low FT4

$65 \%$

$77.2 \%$

Not described

$31 \%$ at the firsst day $79.6 \%$ at the thirrd day $43.7 \%$ at the tenth day

$9.8 \%$

$42 \%$

$40 \%$

T3 levels were lower in 20\%, and fT3 levels were lower in 33\% patients

$16 \%$ of medical ICU patients and $19.3 \%$ of surgical ICU cases

$51.2 \%$

48.8 on admission and $61.3 \%$ on the fifth day

Not described

$67 \%$

Decreased fT3 or fT4 group: 33\% Decreased TSH group: $41 \%$

$60 \%$

$58.7 \%$

$53 \%$
Sampling time

$3^{\circ}$ Day

Within $24 \mathrm{~h}$ of admission

On day $1,5,15$, and last day Not described

1-3 days after admission

On admission and on day 7

In the first 4 days after admission, and consecutively every 8 days after

During the first $24 \mathrm{~h}$, on day 2 , and at discharge from the ICU or death

Blood samples were obtained $24 \mathrm{~h}$ after admission Blood samples colected when sepsis were dianosed

On day 1,3 , and 10

On admission

Within $48 \mathrm{~h}$ of admission

On admission and discharge

First, second, third, and seventh day after admission

On the first to third days after ICU admission.

In the first $24 \mathrm{~h}$

On the day of admission (D1) and fifth day after admission (D5)

On admission

On admission

On the second day.

On the day of initiation of MV 1-3 days after CABG

Most underwent measurements at days 1 $(77.8 \%)$ and $2(13.4 \%)$

CABG, coronary artery bypass grafting; fT3, free triiodothyronine; fT4, free thyroxine; ICU, intensive care unit; MV, mechanical ventilation; rT3, reverse triiodothyronine; T3, triiodothyronine; T4, thyroxine; TSH, thyrotropin.

https://ec.bioscientifica.com

https://doi.org/10.1530/EC-21-0504 (c) 2022 The authors Published by Bioscientifica Ltd

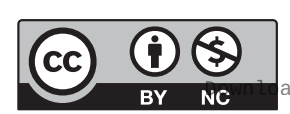

This work is licensed under a Creative Commons Attribution-NonCommercial 4.0 International License. ded from Bioscientifica.com at 04/26/2023 11:47:29AM 


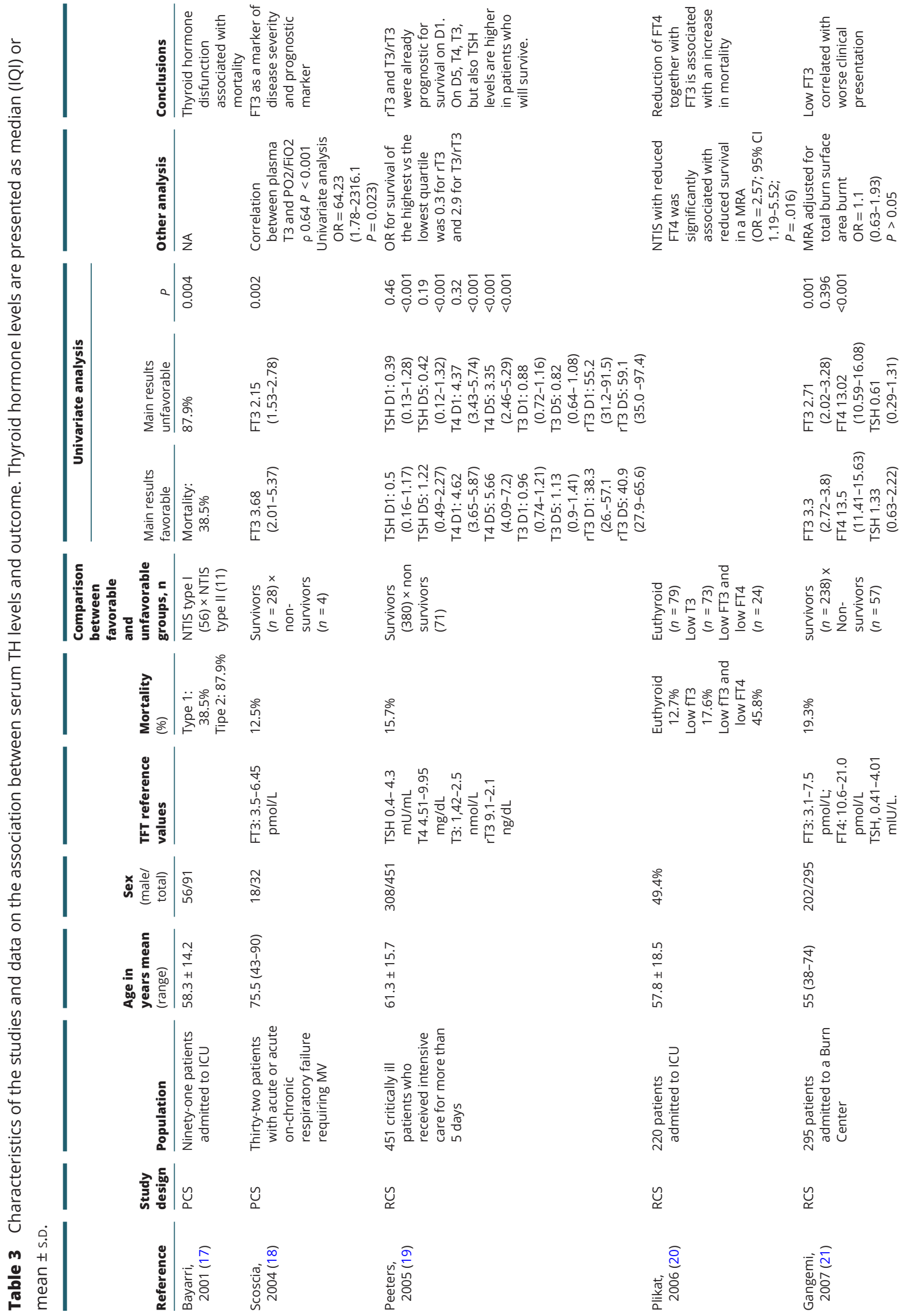




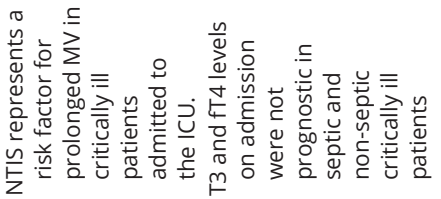

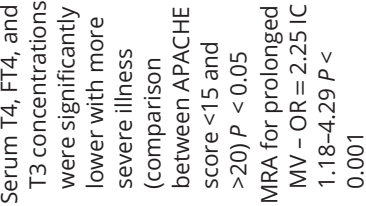

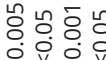

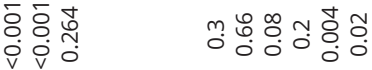

홓ㅎㅁ

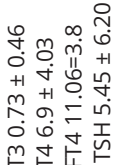

กิก กิำ

0

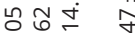

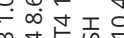

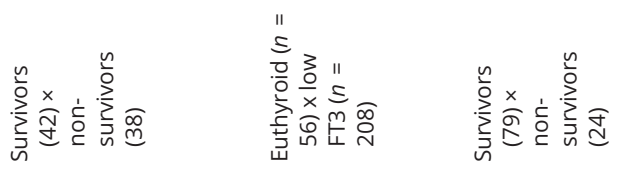

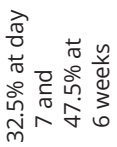

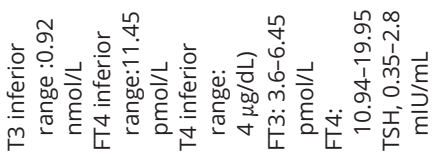

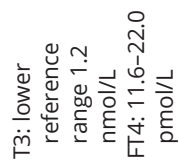

$\stackrel{\infty}{\circ}$

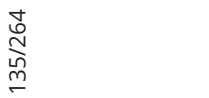

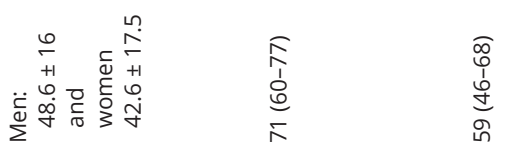
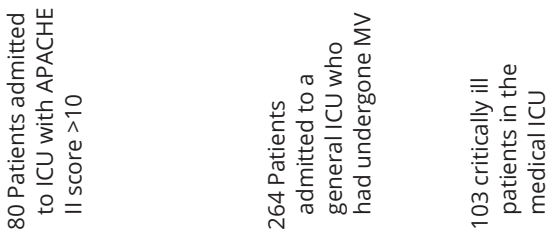

ֻ
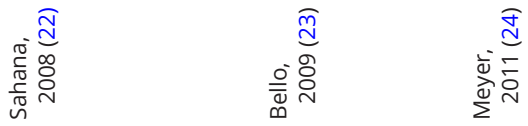

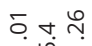

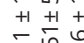

în

鱼吉志

능

$\bar{m}+\dot{+}+\dot{+}$

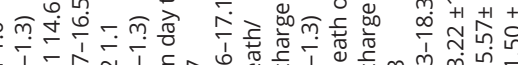

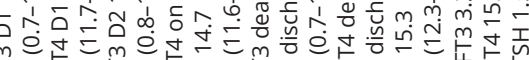
ঃे

ำ

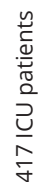

y

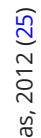

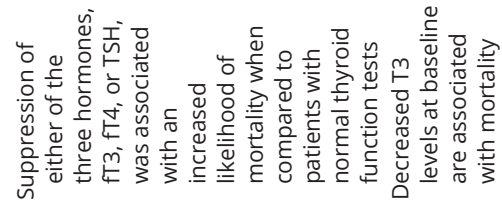

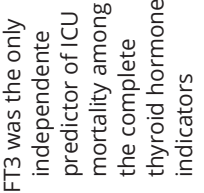

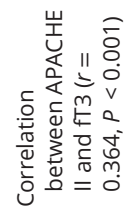

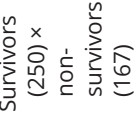

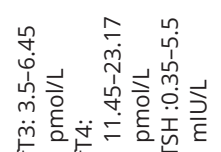

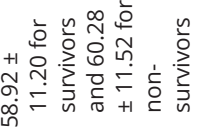

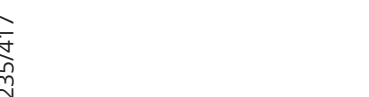

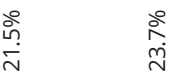

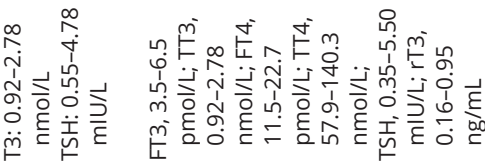

宇

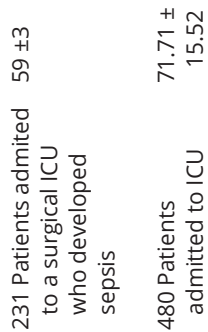

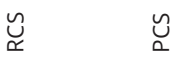

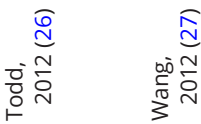

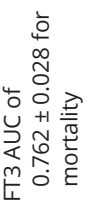

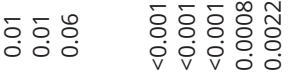

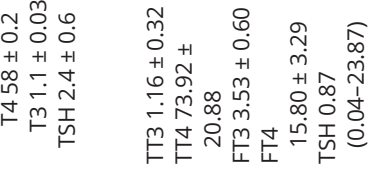

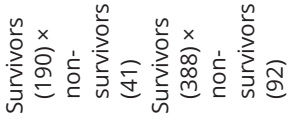

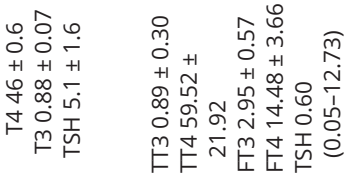

竞

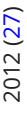

(c) 2022 The authors https://doi.org/10.1530/EC-21-0504 


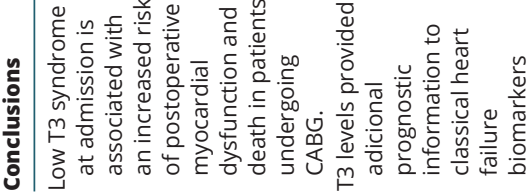

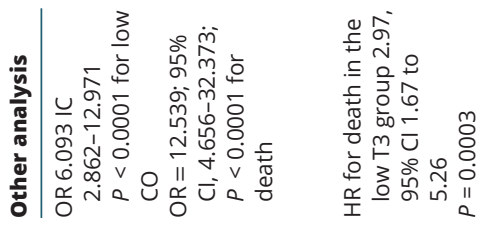

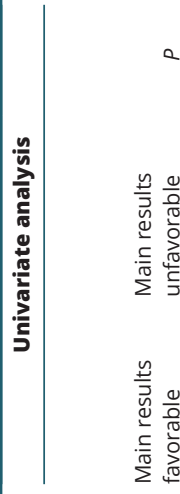

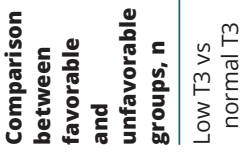

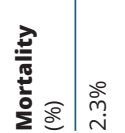

竞

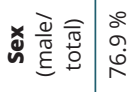

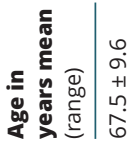

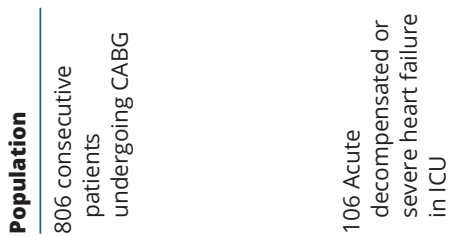

离

$\frac{m}{\frac{m}{0}}$

(c) 2022 The authors Published by Bioscientifica Ltd
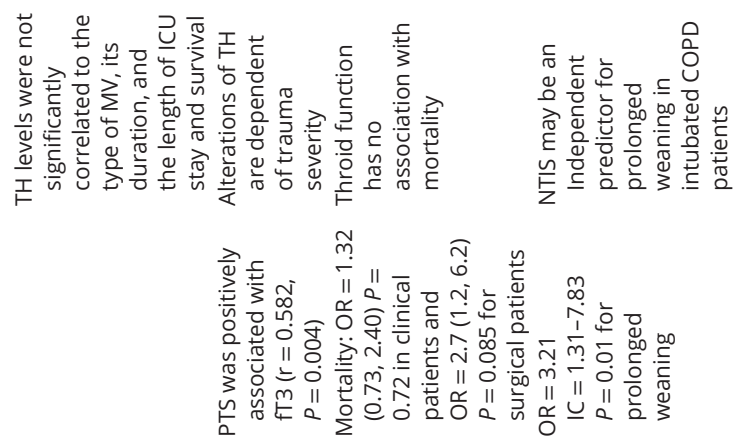

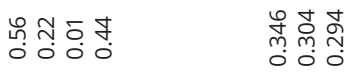

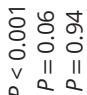

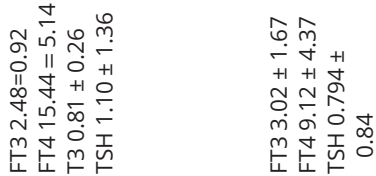

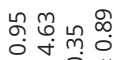

il ${ }^{\prime \prime}$ mo

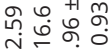

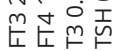

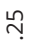

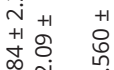

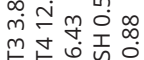

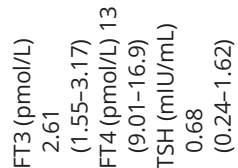

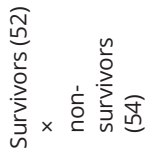

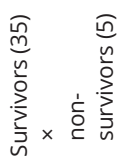

点

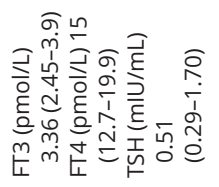

o̊

ণับ

$\stackrel{\text { ํ }}{1}$

$\stackrel{+}{\mathrm{m}}$

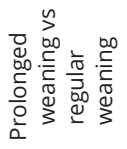

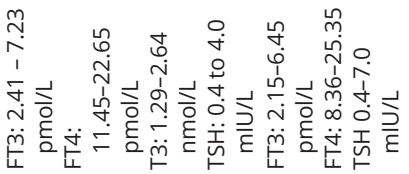

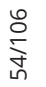

$\frac{\sqrt{2}}{d}$

离

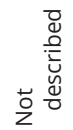

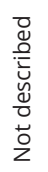

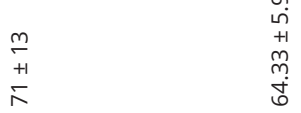

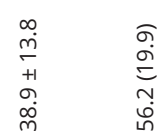

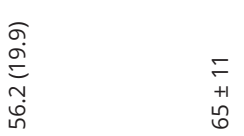

$\stackrel{\text { }}{\stackrel{5}{\circ}}$

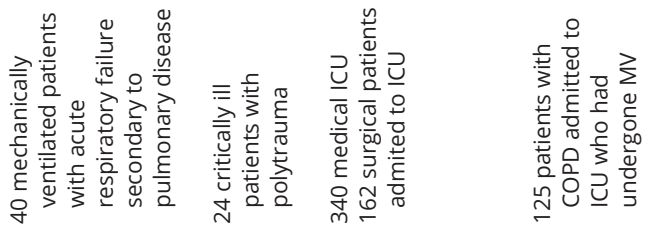

Чับ

气

y.

Чัญ

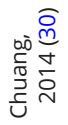

추요

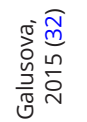

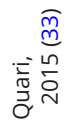

通 


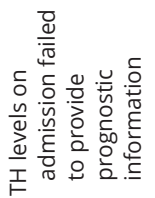

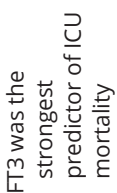

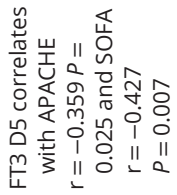

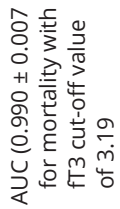

กิํํำ

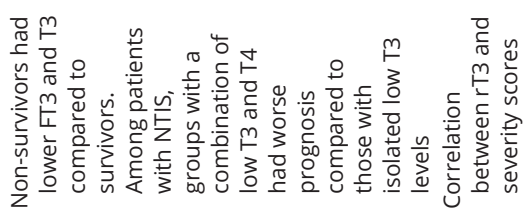

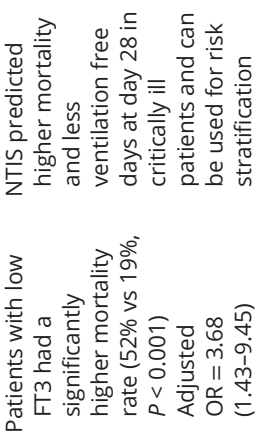

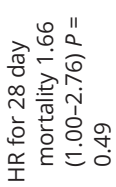

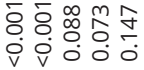

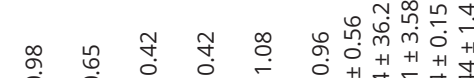

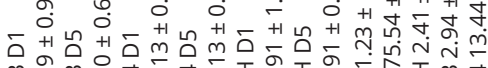

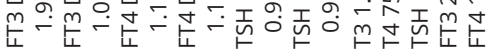

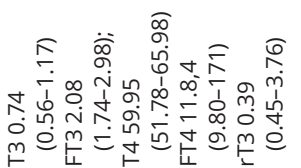

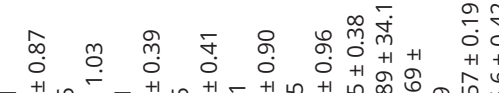

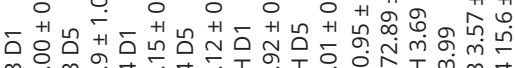

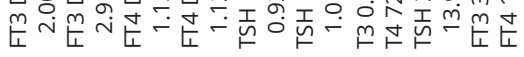

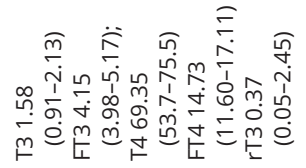

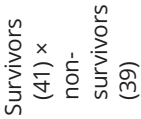

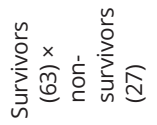

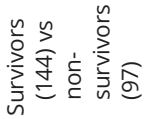

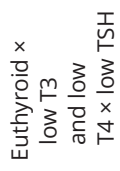

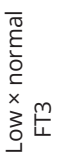

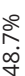<smiles>[CH]1[CH]C1</smiles>



ळั

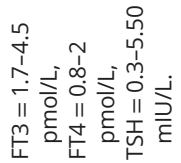

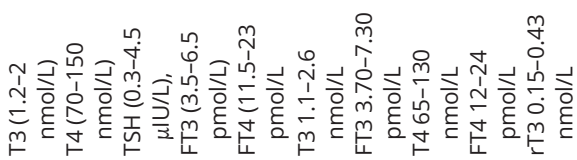

$\stackrel{\infty}{\circ}$

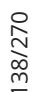

$\underset{\substack{0 \\ \infty}}{\infty}$

$\underset{\substack{n \\ \infty}}{\infty}$

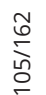

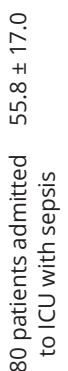

\section{$m$
$\infty$
$\infty$
+1
$\circ$
$\infty$
$\infty$
$m$}

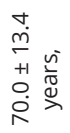

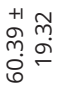

$\infty$
$\infty$
$\oplus$
+
0
0
0
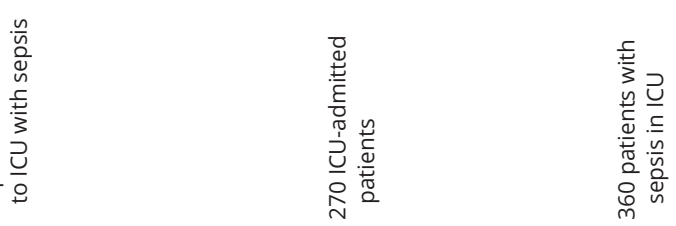

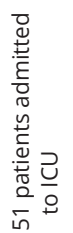

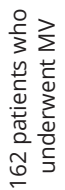

Ч̊

$\dddot{y}$

气ั

气

খ

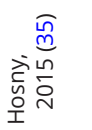

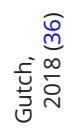

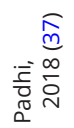

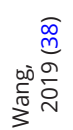

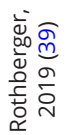




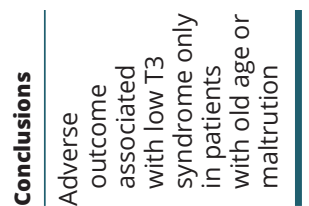

$\frac{5}{8}$

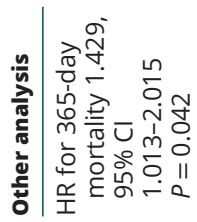

$a$

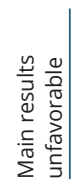

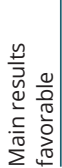

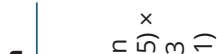

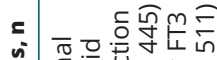

है.

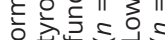
竞 associated with increased mortality risk in both groups, with reduced heterogeneity in patients admitted for noncardiovascular causes (Fig. 4).

\section{Publication bias}

Funnel plot suggested a tendency of publication bias on the metanalysis on mortality risk (P Egger's test $=0.05$, Fig. 5). To adjust for funnel plot asymmetry, we used the trim and fill method for sensitivity analysis, finding increased mortality risk associated with NTIS (random-effects model: OR $1.6049 ; 95 \%$ CI, $1.16-2.21 ; P=0.004)$.

\section{Discussion}

This study is the first systematic review and meta-analysis to evaluate the prevalence and prognostic relevance of NTIS in critically ill patients. According to our results, decreased TH levels, either T3 or T4, are highly prevalent and are associated with an unfavorable outcome in adult patients admitted to ICU. Additionally, the independent mortality risk associated with NTIS suggests the possibility of using $\mathrm{TH}$ measurements as a prognostic factor in this setting.

For decades, NTIS was regarded as an adaptive mechanism to prevent catabolic changes during critical illness (42). Our findings are in accordance with other studies $(13,14,43,44,45,46)$ that consistently suggest no survival advantage and question the generally accepted idea of preservation associated with decreased TH metabolism. Systematic reviews evaluating patients with acute neurologic events $(43,44)$, cardiovascular disease (14), sepsis (13), and chronic renal failure $(45,46)$ point to an incremental risk of unfavorable outcomes in patients with NTIS. Experimental and clinical studies support the hypothesis that reduced serum and tissue concentrations of $\mathrm{T} 3$ may be implicated in organic dysfunction commonly related to the critically ill as diminished cognitive status with lethargy (47), altered cardiac inotropism and chronotropism, altered vasoactive properties $(48,49)$, inability to control bacterial infections due to reduced response of the innate immune system (50), respiratory muscle weakness (51), reduced synthesis of pulmonary surfactant, and decrease of lung compliance resulting in the impairment of lung function (52). The significant correlation between decreased $\mathrm{TH}$ and organic dysfunctions indicates the possibility of the use of $\mathrm{TH}$ as a prognostic factor for the critically ill, as multiple organ 


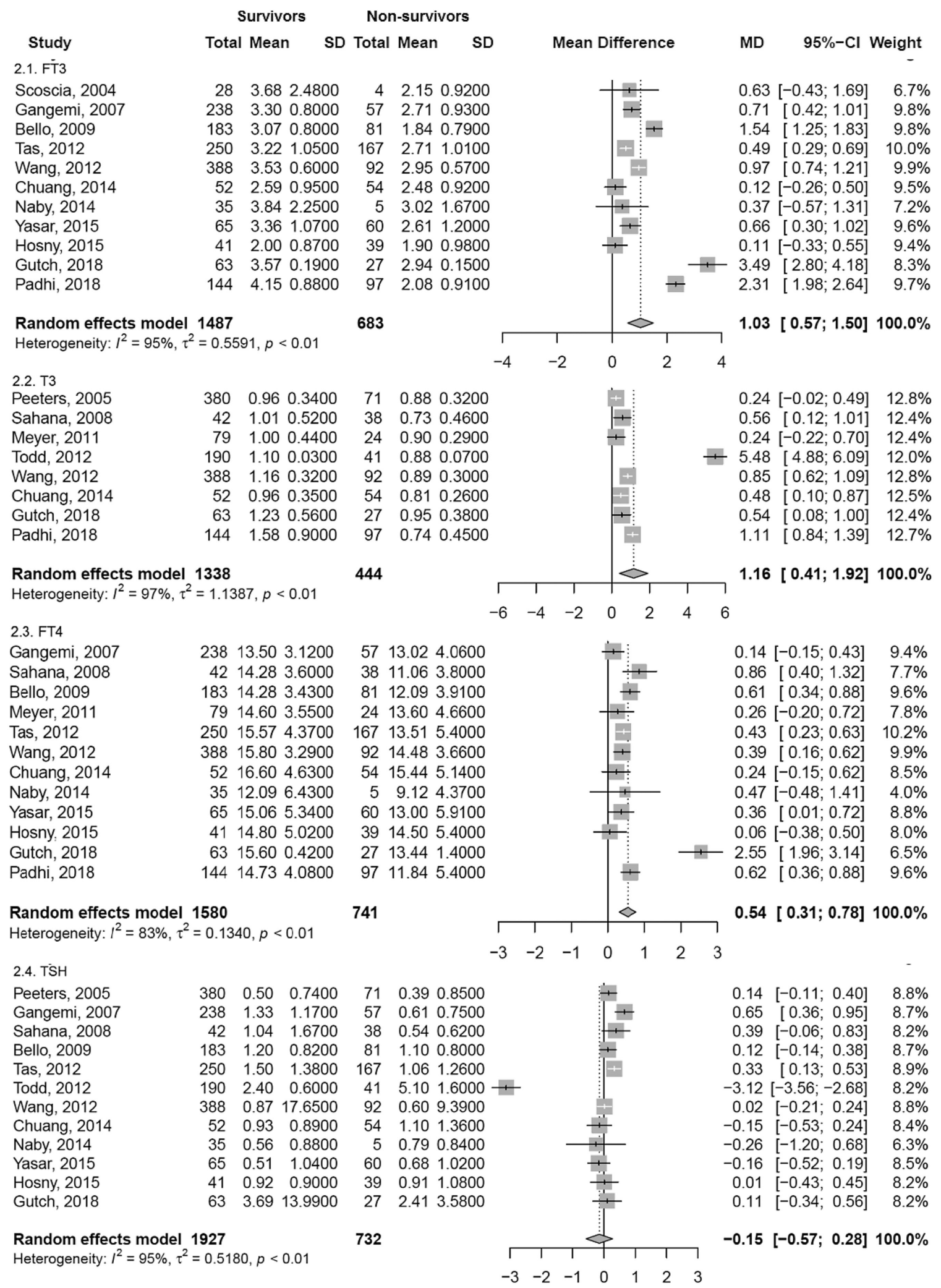

Figure 2

Forest plot of the effect of low thyroid hormone level and mortality.

https://ec.bioscientifica.com

https://doi.org/10.1530/EC-21-0504 (c) 2022 The authors Published by Bioscientifica Ltd

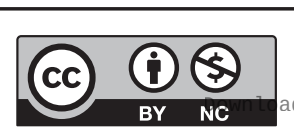

This work is licensed under a Creative Commons Attribution-NonCommercial 4.0 International License. 
Study

Plikat 2006

Gangemi 2007

Bello 2009

Wang F 2012

Cerillo 2014

Chuang 2014

Quari 2015

Quari 2015

Padhi 2018

Rothberger 2019

Wang J 2019

Asai 2020

Random effects model

Heterogeneity: $I^{2}=65 \%, \tau^{2}=0.1666, p<0.01$

TE seTE

Odds Ratio

OR

$95 \%-\mathrm{Cl}$ Weight

0.940 .3900

0.090 .2800

0.810 .3200

0.620 .2500

2.520 .4900

$1.08 \quad 0.2900$

0.270 .3000

0.990 .4100

0.500 .2500

$1.30 \quad 0.4800$

1220.3700

0.350 .1700

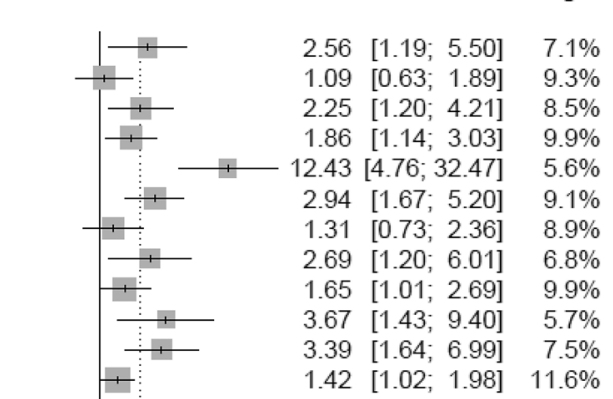

$2.21[1.64 ; 2.97] 100.0 \%$

\section{Figure 3}

Forest plot of the OR for mortality associated with NTIS. dysfunction syndrome is the most frequent cause of death in the ICU (53).

Whether replacing $\mathrm{TH}$ can help to improve the outcomes of NITS patients is still unknown. While some studies are inconclusive regarding the effectiveness of TH therapy in the outcome of patients with NTIS (54, $55)$ with risks associated with overdosage and delayed recovery of the neuroendocrine feedback axis (56), others have shown benefit on secondary endpoints, as reduced protein degradation associated with restoration of plasma $\mathrm{TH}$ levels (57) and increment of cardiac stroke volume (58). Importantly, no of manuscripts here had patients receiving any kind of treatment to NTIS. Nevertheless, it is important to remember that normalization of deranged physiologic parameters in ICU patients has repeatedly proved to be ineffective in improving outcomes when the causal stimulus is not addressed (59).
There were some limitations in this meta-analysis. Firstly, we found high heterogeneities in the statistical results. To address this issue, we performed a pre-specified stratified analysis for confounding factors, such as main diagnosis and methodological quality, which reduced the heterogeneity ( $\mathrm{I}^{2}$ from 65 to $21 \%$ ), showing more reliable results in the risk assessment for mortality in the general admission of ICU patients. Still, we were unable to control for other causes of heterogeneities, like the severity of disease and inconsistence of TH ample sizes, because of insufficient data. Also, data were primarily derived from single-center studies. Although from a geographically diverse population, they might lack the necessary external validity support. Finally, it is unclear if the presence of patients with protracted disease prior to acute illness may influence the results and for this matter we need more studies in the future.

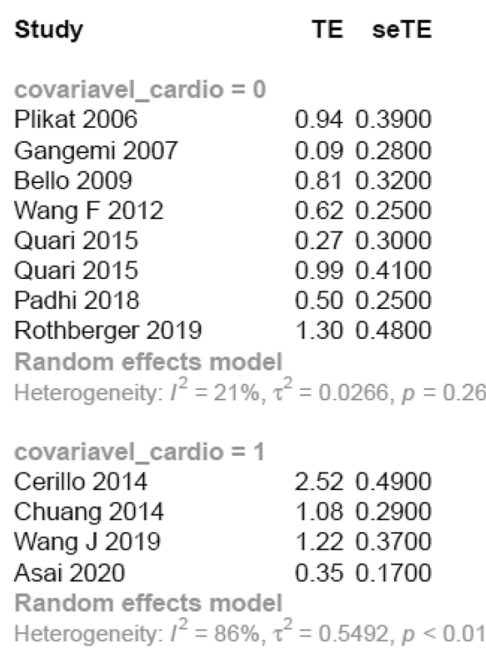

Random effects model

Heterogeneity: $I^{2}=65 \%, \tau^{2}=0.1666, p<0.01$

Residual heterogeneity: $l^{2}=67 \%, p<0.01$

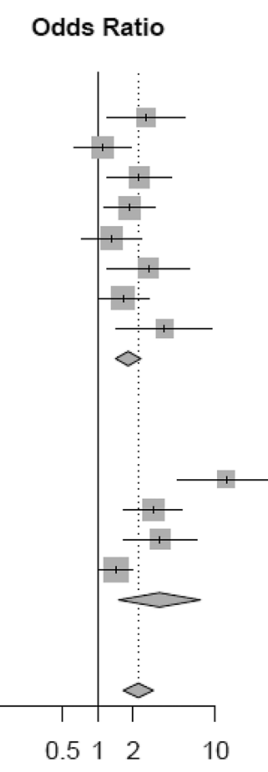

(c) 2022 The authors
OR

$2.56 \quad[1.19 ; 5.50] \quad 7.1 \%$

$1.09[0.63 ; 1.89] \quad 9.3 \%$

$2.25[1.20 ; 4.21] \quad 8.5 \%$

$1.86[1.14 ; 3.03] \quad 9.9 \%$

$1.31 \quad[0.73 ; 2.36] \quad 8.9 \%$

$2.69[1.20 ; 6.01] \quad 6.8 \%$

$1.65[1.01 ; 2.69] \quad 9.9 \%$

$3.67[1.43 ; 9.40] \quad 5.7 \%$

$1.81[1.42 ; 2.32] \quad 66.2 \%$

$12.43[4.76 ; 32.47] \quad 5.6 \%$

$2.94[1.67 ; 5.20] \quad 9.1 \%$

$3.39[1.64 ; 6.99] \quad 7.5 \%$

$1.42[1.02 ; 1.98] \quad 11.6 \%$

$3.34[1.51 ; 7.43] \quad 33.8 \%$

$2.21[1.64 ; 2.97] 100.0 \%$

Figure 4

Forest plot of the OR for mortality in a stratified analysis for cause of admission. https://ec.bioscientifica.com

https://doi.org/10.1530/EC-21-0504
Published by Bioscientifica Ltd

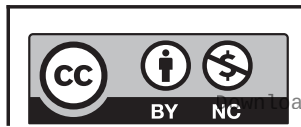

This work is licensed under a Creative Commons Attribution-NonCommercial 4.0 International License. ded from Bioscientifica.com at 04/26/2023 11:47:29AM via free access 


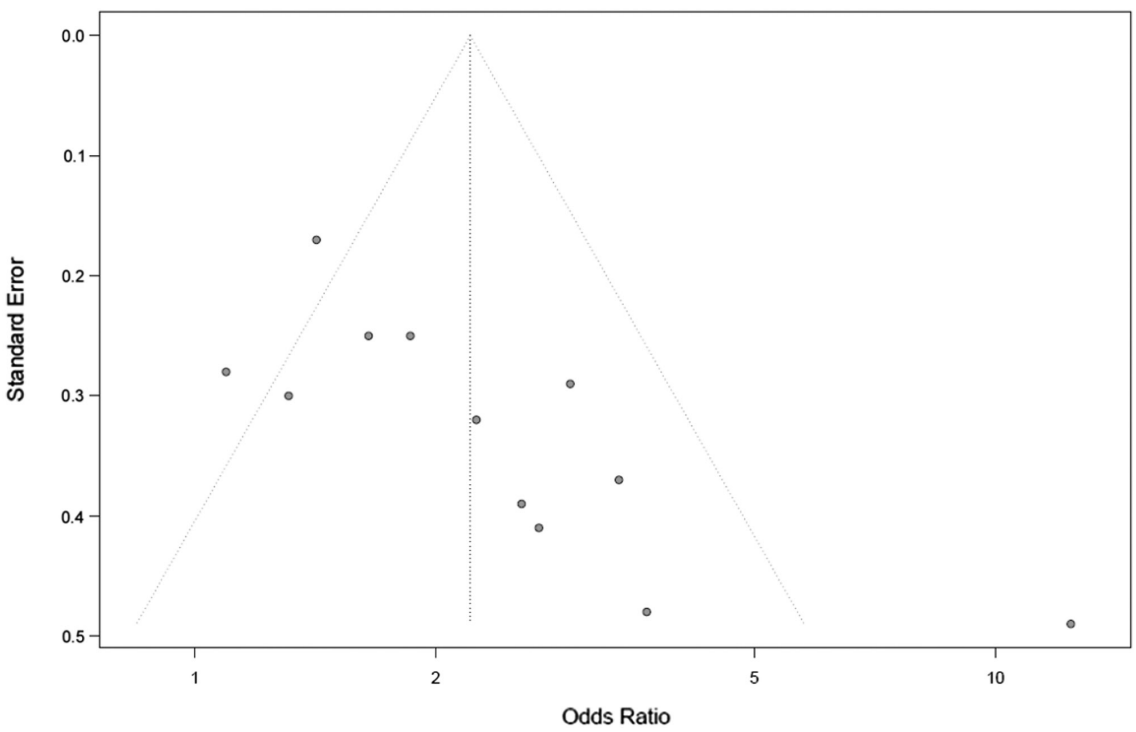

Figure 5

Funnel plot of publication bias.

\section{Conclusion}

The findings of this systematic review and meta-analysis suggest that NTIS is highly prevalent in the critically ill population and that decreased serum T3 or T4 levels are associated with mortality in adult ICU patients. Based on these findings, the measurement of serum T3 or T4 levels could provide better information-related prognosis in this setting.

\section{Supplementary materials}

This is linked to the online version of the paper at https://doi.org/10.1530/ EC-21-0504.

\section{Declaration of interest}

The authors declare that there is no conflict of interest that could be perceived as prejudicing the impartiality of the research reported.

\section{Funding}

This work was supported by FIPE/HCPA - Hospital de Clínicas de Porto Alegre Research Incentive Fund (0170492) and CNPq - National Council for Scientific and Technological development (301585/2018-0).

\section{References}

1 Van den Berghe G. Non-thyroidal illness in the ICU: a syndrome with different faces. Thyroid 201424 1456-1465. (https://doi.org/10.1089/ thy.2014.0201)

2 Kaptein EM, Robinson WJ, Grieb DA \& Nicoloff JT. Peripheral serum thyroxine, triiodothyronine and reverse triiodothyronine kinetics in the low thyroxine state of acute nonthyroidal illnesses. A noncompartmental analysis. Journal of Clinical Investigation 198269 526-535. (https://doi.org/10.1172/jci110478)
3 Maia AL, Goemann IM, Meyer EL \& Wajner SM. Deiodinases: the balance of thyroid hormone: type 1 iodothyronine deiodinase in human physiology and disease. Journal of Endocrinology 2011209 283-297. (https://doi.org/10.1530/JOE-10-0481)

4 Peeters RP, Wouters PJ, Kaptein E, van Toor H, Visser TJ \& Van den Berghe G. Reduced activation and increased inactivation of thyroid hormone in tissues of critically ill patients. Journal of Clinical Endocrinology and Metabolism 200388 3202-3211. (https://doi. org/10.1210/jc.2002-022013)

5 De Groot LJ. Dangerous dogmas in medicine: the nonthyroidal illness syndrome. Journal of Clinical Endocrinology and Metabolism 199984 151-164. (https://doi.org/10.1210/jcem.84.1.5364)

6 Moreno RP, Metnitz PG, Almeida E, Jordan B, Bauer P, Campos RA, Lapichino G, Edbrooke D, Capuzzo M, Le Gall JR, et al. SAPS 3-from evaluation of the patient to evaluation of the intensive care unit. Part 2: Development of a prognostic model for hospital mortality at ICU admission. Intensive Care Medicine 200531 1345-1355. (https://doi. org/10.1007/s00134-005-2763-5)

7 Vincent JL, de Mendonça A, Cantraine F, Moreno R, Takala J, Suter PM, Sprung CL, Colardyn F \& Blecher S. Use of the SOFA score to assess the incidence of organ dysfunction/failure in intensive care units: results of a multicenter, prospective study. Working group on 'sepsis-related problems' of the European Society of Intensive Care Medicine. Critical Care Medicine 199826 1793-1800.

8 Zimmerman JE, Kramer AA, McNair DS \& Malila FM. Acute Physiology and Chronic Health Evaluation (APACHE) IV: hospital mortality assessment for today's critically ill patients. Critical Care Medicine 200634 1297-1310. (https://doi.org/10.1097/01.

CCM.0000215112.84523.F0)

9 Ferreira FL, Bota DP, Bross A, Melot C \& Vincent JL. Serial evaluation of the SOFA score to predict outcome in critically ill patients. JAMA 2001 286 1754-1758. (https://doi.org/10.1001/jama.286.14.1754)

10 Keegan MT \& Soares M. What every intensivist should know about prognostic scoring systems and risk-adjusted mortality. Revista Brasileira de Terapia Intensiva 201628 264-269. (https://doi. org/10.5935/0103-507X.20160052)

11 Iervasi G, Pingitore A, Landi P, Raciti M, Ripoli A, Scarlattini M, L'Abbate A \& Donato L. Low-T3 syndrome: a strong prognostic predictor of death in patients with heart disease. Circulation 2003107 708-713. (https://doi.org/10.1161/01.cir.0000048124.64204.3f)

12 Iglesias P, Muñoz A, Prado F, Guerrero MT, Macías MC, Ridruejo E, Tajada P \& Díez JJ. Alterations in thyroid function tests in aged hospitalized patients: prevalence, aetiology and clinical outcome. 
Clinical Endocrinology 200970 961-967. (https://doi.org/10.1111/j.13652265.2008.03421.x)

13 Kim JG, Shin H, Kim W, Lim TH, Jang B, Cho Y, Choi KS, Ahn C, Lee J $\&$ Na MK. The value of decreased thyroid hormone for predicting mortality in adult septic patients: a systematic review and metaanalysis. Scientific Reports $2018 \mathbf{8} 14137$.

14 Wang B, Liu S, Li L, Yao Q, Song R, Shao X, Li Q, Shi X \& Zhang JA. Non-thyroidal illness syndrome in patients with cardiovascular diseases: a systematic review and meta-analysis. International Journal of Cardiology 2017226 1-10. (https://doi.org/10.1016/j. ijcard.2016.10.039)

15 Moher D, Liberati A, Tetzlaff J, Altman DG \& PRISMA Group. Preferred reporting items for systematic reviews and meta-analyses: the PRISMA statement. Journal of Clinical Epidemiology 200962 1006-1012. (https://doi.org/10.1016/j.jclinepi.2009.06.005)

16 SIGN. SIGN 50: A Guideline Developer's Handbook. Edinburgh, UK: SIGN, 2015. (available at: https://www.sign.ac.uk/media/1644/ sign50_2015.pdf)

17 Asai K, Shirakabe A, Kiuchi K, Kobayashi N, Okazaki H, Matsushita M, Shibata Y, Goda H, Shigihara S, Asano K, et al. Relation of low triiodothyronine syndrome associated with aging and malnutrition to adverse outcome in patients with acute heart failure. American Journal of Cardiology 2020125 427-435. (https://doi.org/10.1016/j. amjcard.2019.10.051)

18 Bello G, Pennisi MA, Montini L, Silva S, Maviglia R, Cavallaro F, Bianchi A, De Marinis L \& Antonelli M. Nonthyroidal illness syndrome and prolonged mechanical ventilation in patients admitted to the ICU. Chest 2009135 1448-1454. (https://doi.org/10.1378/ chest.08-1816)

19 Cerillo AG, Storti S, Kallushi E, Haxhiademi D, Miceli A, Murzi M, Berti S, Glauber M, Clerico A \& Iervasi G. The low triiodothyronine syndrome: a strong predictor of low cardiac output and death in patients undergoing coronary artery bypass grafting. Annals of Thoracic Surgery 201497 2089-2095. (https://doi.org/10.1016/j. athoracsur.2014.01.049)

20 Chuang CP, Jong YS, Wu CY \& Lo HM. Impact of triiodothyronine and $\mathrm{N}$-terminal pro-B-type natriuretic peptide on the long-term survival of critically ill patients with acute heart failure. American Journal of Cardiology 2014113 845-850. (https://doi.org/10.1016/j. amjcard.2013.11.039)

21 Galusova A, Pauliny M, Majek M, Mackova J, Meskova M, Vlcek M, Imrich R \& Penesova A. Dynamic neuroendocrine changes in critically ill patients with polytrauma. Neuro Endocrinology Letters 201536 498-503.

22 Gangemi EN, Garino F, Berchialla P, Martinese M, Arecco F, Orlandi F \& Stella M. Low triiodothyronine serum levels as a predictor of poor prognosis in burn patients. Burns 200834 817-824. (https://doi org/10.1016/j.burns.2007.10.002)

23 Gutch M, Kumar S \& Gupta KK. Prognostic value of thyroid profile in critical care condition. Indian Journal of Endocrinology and Metabolism 201822 387-391. (https://doi.org/10.4103/ijem.JJEM_20_18)

24 Hosny M, Rashad R, Atef D \& Abed N. Predictive value of thyroid hormone assessment in septic patients in comparison with C-reactive protein. Egyptian Journal of Critical Care Medicine 20153 55-61.

25 Meyer S, Schuetz P, Wieland M, Nusbaumer C, Mueller B \& ChristCrain M. Low triiodothyronine syndrome: a prognostic marker for outcome in sepsis? Endocrine 201139 167-174. (https://doi. org/10.1007/s12020-010-9431-4)

26 Miguel Bayarri V, Borrás Palle S, Murcia Llácer B, Sancho Chinesta S, Málaga López A, Solá Izquierdo E, Pérez Bermúdez B \& Hernández Mijares A. Prevalence and prognosis significance of euthyroid sick syndrome in critical illness. Revista Clínica Española 2001201 572-574. (https://doi.org/10.1016/s0014-2565(01)70916-2)

27 Naby EAA, Selim S, Mohsen M \& Helmy M. Thyroid function in mechanically ventilated patients with acute respiratory failure: prognostic value and its relation to high-sensitivity C-reactive protein. Egyptian Journal of Chest Diseases and Tuberculosis 201564 175-181.
28 Nafae RM, Mohammed MA, Morsi AF \& Ibrahim DA. Thyroid function in respiratory failure patients. Egyptian Journal of Chest Diseases and Tuberculosis 201463 513-521. (https://doi.org/10.1016/j. ejcdt.2013.12.009)

29 Padhi R, Kabi S, Panda BN \& Jagati S. Prognostic significance of nonthyroidal illness syndrome in critically ill adult patients with sepsis. International Journal of Critical Illness and Injury Science $2018 \mathbf{8}$ 165-172. (https://doi.org/10.4103/IJCIIS.IJCIIS_29_17)

30 Peeters RP, Wouters PJ, van Toor H, Kaptein E, Visser TJ \& Van den Berghe G. Serum 3,3',5'-triiodothyronine (rT3) and 3,5,3'-triiodothyronine/rT3 are prognostic markers in critically ill patients and are associated with postmortem tissue deiodinase activities. Journal of Clinical Endocrinology and Metabolism 200590 4559-4565. (https://doi.org/10.1210/jc.2005-0535)

31 Plikat K, Langgartner J, Buettner R, Bollheimer LC, Woenckhaus U, Schölmerich J \& Wrede CE. Frequency and outcome of patients with nonthyroidal illness syndrome in a medical intensive care unit. Metabolism: Clinical and Experimental 200756 239-244. (https://doi. org/10.1016/j.metabol.2006.09.020)

32 Qari FA. Thyroid function status and its impact on clinical outcome in patients admitted to critical care. Pakistan Journal of Medical Sciences 201531 915-919. (https://doi.org/10.12669/pjms.314.7497)

33 Rothberger GD, Valestra PK, Knight K, Desai AK, Calixte R \& Shapiro LE. Low free T3 is associated with worse outcomes in patients in the ICU requiring invasive mechanical ventilation. Journal of Intensive Care Medicine 202136 313-318. (https://doi. org/10.1177/0885066619890822)

34 Sahana PK, Ghosh A, Mukhopadhyay P, Pandit K, Chowdhury BR \& Chowdhury S. A study on endocrine changes in patients in intensive care unit. Journal of the Indian Medical Association 2008106 362-364.

35 Scoscia E, Baglioni S, Eslami A, Iervasi G, Monti S \& Todisco T. Low triiodothyronine (T3) state: a predictor of outcome in respiratory failure? Results of a clinical pilot study. European Journal of Endocrinology 2004151 557-560. (https://doi.org/10.1530/eje.0.1510557)

36 Tas A, Tetiker T, Beyazit Y, Celik H \& Yesil Y. Thyroid hormone levels as a predictor of mortality in intensive care patients: a comparative prospective study. Wiener Klinische Wochenschrift 2012124 154-159. (https://doi.org/10.1007/s00508-012-0125-1)

37 Todd SR, Sim V, Moore LJ, Turner KL, Sucher JF \& Moore FA. The identification of thyroid dysfunction in surgical sepsis. Journal of Trauma and Acute Care Surgery 201273 1457-1460. (https://doi. org/10.1097/TA.0b013e318270db2c)

38 Wang F, Pan W, Wang H, Wang S, Pan S \& Ge J. Relationship between thyroid function and ICU mortality: a prospective observation study. Critical Care 201216 R11. (https://doi.org/10.1186/cc11151)

39 Wang J, Yuan W, Dong R, Liu N, Liu D \& Zhou Y. Predictors for euthyroid sick syndrome and its impact on in-hospital clinical outcomes in high-risk patients undergoing coronary artery bypass grafting. Perfusion 201934 679-688. (https://doi. org/10.1177/0267659119846789)

40 Wang YF, Heng JF, Yan J \& Dong L. LRelationship between disease severity and thyroid function in Chinese patients with euthyroid sick syndrome. Medicine 201897 e11756. (https://doi.org/10.1097/ MD.0000000000011756)

41 Yasar Z, Kirakli C, Cimen P, Ucar ZZ, Talay F \& Tibet G. Is non-thyroidal illness syndrome a predictor for prolonged weaning in intubated chronic obstructive pulmonary disease patients? International Journal of Clinical and Experimental Medicine 20158 10114-10121.

42 Van den Berghe G. The neuroendocrine response to stress is a dynamic process. Best Practice and Research: Clinical Endocrinology and Metabolism 200115 405-419. (https://doi.org/10.1053/beem.2001.0160)

43 Jiang X, Xing H, Wu J, Du R, Liu H, Chen J, Wang J, Wang C \& Wu Y. Prognostic value of thyroid hormones in acute ischemic stroke - a meta analysis. Scientific Reports $2017 \mathbf{7} 16256$.

44 Lamba N, Liu C, Zaidi H, Broekman MLD, Simjian T, Shi C, Doucette J, Ren S, Smith TR, Mekary RA, et al. A prognostic role for low tri- 
iodothyronine syndrome in acute stroke patients: a systematic review and meta-analysis. Clinical Neurology and Neurosurgery 2018169 55-63. (https://doi.org/10.1016/j.clineuro.2018.03.025)

45 Schultheiss UT, Steinbrenner I, Nauck M , Schneider MP, Kotsis F, Baid-Agrawal S, Schaeffner E, Eckardt K-U, Köttgen A, Sekula P, et al. Thyroid function, renal events and mortality in chronic kidney disease patients: the German Chronic Kidney Disease study. Clinical Kidney Journal 202114 959-968. (https://doi.org/10.1093/ckj/ sfaa052)

46 Xu H, Brusselaers N, Lindholm B, Zoccali C \& Carrero JJ. Thyroid function test derangements and mortality in dialysis patients: a systematic review and meta-analysis. American Journal of Kidney Diseases 201668 923-932. (https://doi.org/10.1053/j. ajkd.2016.06.023)

47 Vaughan GM, Mason AD, Jr, McManus WF \& Pruitt BA, Jr. Alterations of mental status and thyroid hormones after thermal injury. Journal of Clinical Endocrinology and Metabolism 198560 1221-1225. (https://doi. org/10.1210/jcem-60-6-1221)

48 Kim BB, Ku YH, Han JY, Ha JM, Park G, Choi DH \& Song H. Relation of triiodothyronine to subclinical myocardial injury in patients with chest pain. American Journal of Cardiology 2013111 1087-1091. (https://doi.org/10.1016/j.amjcard.2012.12.039)

49 Pol CJ, Muller A, Zuidwijk MJ, van Deel ED, Kaptein E, Saba A, Marchini M, Zucchi R, Visser TJ, Paulus WJ, et al. Left-ventricular remodeling after myocardial infarction is associated with a cardiomyocyte-specific hypothyroid condition. Endocrinology 2011 152 669-679. (https://doi.org/10.1210/en.2010-0431)

50 Boelen A, Boorsma J, Kwakkel J, Wieland CW, Renckens R, Visser TJ, Fliers E \& Wiersinga WM. Type 3 deiodinase is highly expressed in infiltrating neutrophilic granulocytes in response to acute bacterial infection. Thyroid 200818 1095-1103. (https://doi.org/10.1089/ thy.2008.0090)

51 Siafakas NM, Salesiotou V, Filaditaki V, Tzanakis N, Thalassinos N \& Bouros D. Respiratory muscle strength in hypothyroidism. Chest 1992 102 189-194. (https://doi.org/10.1378/chest.102.1.189)
52 Dulchavsky SA, Kennedy PR, Geller ER, Maitra SR, Foster WM \& Langenbeck EG. T3 preserves respiratory function in sepsis. Journal of Trauma 199131 753-758; discussion 8-9. (https://doi. org/10.1097/00005373-199106000-00004)

53 Mayr VD, Dunser MW, Greil V, Jochberger S, Luckner G, Ulmer H, Friesenecker BE, Takala J \& Hasibeder WR. Causes of death and determinants of outcome in critically ill patients. Critical Care $2006 \mathbf{1 0}$ R154. (https://doi.org/10.1186/cc5086)

54 Kaptein EM, Beale E \& Chan LS. Thyroid hormone therapy for obesity and nonthyroidal illnesses: a systematic review. Journal of Clinical Endocrinology and Metabolism 200994 3663-3675. (https://doi. org/10.1210/jc.2009-0899)

55 Kaptein EM, Sanchez A, Beale E \& Chan LS. Clinical review: Thyroid hormone therapy for postoperative nonthyroidal illnesses: a systematic review and synthesis. Journal of Clinical Endocrinology and Metabolism 201095 4526-4534. (https://doi.org/10.1210/jc.20101052)

56 Brent GA \& Hershman JM. Thyroxine therapy in patients with severe nonthyroidal illnesses and low serum thyroxine concentration. Journal of Clinical Endocrinology and Metabolism 198663 1-8. (https:// doi.org/10.1210/jcem-63-1-1)

57 Van den Berghe G, de Zegher F \& Bouillon R. Clinical review 95: Acute and prolonged critical illness as different neuroendocrine paradigms. Journal of Clinical Endocrinology and Metabolism 199883 1827-1834. (https://doi.org/10.1210/jcem.83.6.4763)

58 Pingitore A, Mastorci F, Piaggi P, Donato Aquaro GD, Molinaro S, Ravani M, De Caterina A, Trianni G, Ndreu R, Berti S, et al. Usefulness of triiodothyronine replacement therapy in patients with ST elevation myocardial infarction and borderline/reduced triiodothyronine levels (from the THIRST Study). American Journal of Cardiology 2019123 905-912. (https://doi.org/10.1016/j. amjcard.2018.12.020)

59 Kavanagh BP \& Meyer LJ. Normalizing physiological variables in acute illness: five reasons for caution. Intensive Care Medicine 200531 1161-1167. (https://doi.org/10.1007/s00134-005-2729-7)

Received in final form 20 December 2021

Accepted 11 January 2022

Accepted Manuscript published online 11 January 2022
This work is licensed under a Creative Commons Attribution-NonCommercial 4.0 International License. ded from Bioscientifica.com at 04/26/2023 11:47:29AM 